Arq. Bras. Med. Vet. Zootec., v.66, n.5, p.1419-1426, 2014

\title{
Anatomical aspects of the nerves of the leg and foot of the giant anteater (Myrmecophaga tridactyla, Linnaeus, 1758)
}

[Aspectos anatômicos dos nervos da perna e pé do tamanduá-bandeira

(Myrmecophaga tridactyla, Linnaeus, 1758)]

\author{
V.S. Cruz ${ }^{1}$, J.C. Cardoso ${ }^{1}$, L.B.M. Araújo ${ }^{2}$, P.R. Souza ${ }^{1}$, M.S.B. Silva ${ }^{1}$, E.G. Araújo ${ }^{2}$ \\ ${ }^{1}$ Universidade Federal de Goiás - Instituto de Ciências Biológicas - Goiânia, GO \\ ${ }^{2}$ Universidade Federal de Goiás - Escola de Veterinária e Zootecnia - Goiânia, GO
}

\begin{abstract}
Although distal stifle joint nerve distribution has been well established in domestic animals, this approach is scarcely reported in wild animals. Therefore, the aim of this study was to describe the nerves of the leg and foot of Myrmecophaga tridactyla with emphasis on their ramification, distribution, topography and territory of innervation. For this purpose, six adult cadavers fixed and preserved in $10 \%$ formalin solution were used. The nerves of the leg and foot of the $M$. tridactyla were the saphenous nerve (femoral nerve branch), fibular and tibial nerves and lateral sural cutaneous nerve (branches of the sciatic nerve) and caudal sural cutaneous nerve (tibial nerve branch). The saphenous nerve branches to the skin, the craniomedial surface of the leg, the medial surface of the tarsal and metatarsal regions and the dorsomedial surface of the digits I and II ( $100 \%$ of cases), III ( $50 \%$ of cases) and IV (25\% of cases). The lateral sural cutaneous nerve innervates the skin of the craniolateral region of the knee and leg. The fibular nerve innervates the flexor and extensor muscles of the tarsal region of the digits and skin of the craniolateral surface of the leg and dorsolateral surface of the foot. The tibial nerve innervates the extensor muscles of the tarsal joint and flexor, adductor and abductor muscles of the digits and the skin of the plantar surface. The caudal sural cutaneous nerve innervates the skin of the caudal surface of the leg. The nerves responsible for the leg and foot innervation were the same as reported in domestic and wild animals, but with some differences, such as the more distal division of the common fibular nerve, the absence of dorsal metatarsal branches of the deep fibular nerve and a greater involvement of the saphenous nerve in the digital innervation with branches to the digits III and IV, in addition to digits I and II.
\end{abstract}

Keywords: pelvic limb, peripheral nervous system, Xenarthra

\section{RESUMO}

Apesar de bem estabelecida nos animais domésticos, a abordagem da distribuição nervosa distal do joelho é rara em animais selvagens. Portanto, o objetivo deste estudo foi descrever os nervos da perna e pé do Myrmecophaga tridactyla, com ênfase na sua ramificação, distribuição, topografia e território de inervação. Para tanto, foram utilizados seis cadáveres adultos, fixados e conservados em solução de formalina a 10\%. A dissecação envolveu desde a formação dos nervos femoral e isquiático pelos ramos ventrais dos nervos espinhais lombares e sacrais até sua distribuição nos territórios propostos. Os nervos responsáveis pela inervação da perna e pé do M. tridactyla foram o N. safeno (ramo do $N$. femoral), os nervos fibular comum e tibial e o N. cutâneo lateral da sura (derivados do N. isquiático) e o $N$. cutâneo caudal da sura (ramo do N. tibial). O nervo safeno emite ramos cutâneos para a superfície craniomedial da perna, medial do tarso e metatarso e dorsomedial dos dedos I e II (100\% dos casos), III (50\% dos casos) e IV (25\% dos casos). O nervo cutâneo lateral da sura inerva a região cutânea craniolateral do joelho e perna. O nervo fibular inerva os músculos flexores do tarso e extensores dos dedos e a região cutânea craniolateral da perna e dorsolateral do pé. O nervo tibial inerva os músculos

Recebido em 6 de fevereiro de 2013

Aceito em 16 de dezembro de 2013

E-mail: souzacruzviviane@gmail.com 
extensores do tarso e flexores, adutores e abdutores dos dedos e região cutânea plantar. O nervo cutâneo caudal da sura inerva a pele da face caudal da perna. Pode-se concluir que os nervos responsáveis pela inervação da perna e pé foram os mesmos relatados em animais domésticos e selvagens, porém com algumas diferenças, como a divisão mais distal do nervo fibular comum, ausência de ramos metatarsianos dorsais do N. fibular profundo e uma maior participação do nervo safeno na inervação digital, contribuindo com ramos inclusive para os dedos III e IV, além dos dedos I e II.

Palavras-chave: membro pélvico, sistema nervoso periférico, Xenarthra

\section{INTRODUCTION}

The Myrmecophaga tridactyla is the largest mammal in the Xenarthra Superorder, which has recently been subdivided into the Cingulata (represented by the armadillo) and Pilosa (represented by the anteater and the sloth) orders (Vizcaíno and Loughry, 2008). The closest relatives of the same family are the Tamandua tetradactyla (lesser anteater) and the Cyclopes didactylus (silky anteater), both arboreal and smaller (Shaw et al., 1987). They inhabit the fields and savannas of the south of Belize and Guatemala up to the north of Argentina including the entire Brazilian territory (Mourão and Medri, 2007). They have laterally flattened bodies, fairly short limbs and plantigrade locomotion. The hands have long nails, which bend inwards whilst in motion (Shaw et al., 1987).

The number of anteaters that have been run over has increased due to the growing number of roads running through its habitat and their necessity to move around searching for food (Braga, 2009). Additionally, the giant anteater is the large mammal most affected by bushfires (Silveira et al., 1999). For these and other reasons, this species is described as "almost threatened by extinction" (NT) in the International Union for Conservation of the Nature and Resources (IUCN, 2012) list, and "vulnerable" at a national level (Barreto, 2007).

The femoral, saphenous, sciatic, common fibular, tibial and lateral cutaneous and caudal cutaneous sural nerves are responsible for the sensitive and motor innervation of the leg and foot of domestic (Getty, 1986; Schaller, 1999; Dyce et al., 2010) and wild animals (Aydin, 2009; Castro et al., 2009). Injuries to these nerves cause a variety of deficiencies, such as loss of sensitivity, muscular movement or both, in a restricted area supplied by the nerve or nerves involved (Lorenz and Kornegay, 2006).
There is lack of data related to distal innervation of the locomotive limbs in wild animals and to date there are no records of studies of this nature in the pelvic limbs of any species in the Xenarthra superorder. Thus, this study presents unpublished and important information for many areas, especially in comparative anatomy, clinical practice, anaesthesiology and surgery of wild animals.

Therefore, the aim of this study was to present a description of the nerves of the leg and foot of the M. tridactyla, with emphasis on its ramification, distribution, topography and territory of innervation.

\section{MATERIAL AND METHODS}

Twelve pelvic limbs of six adult giant anteaters (three females, two males and one undefined due to removal of genital organs in a necropsy procedure) were examined in this study. The cadavers were provided by IBAMA - Brazilian Institute of Environment and Renewable Natural Resources) (license 99/2011) and the experimental protocol has been approved by the Ethics Committee for Animal Use of the Federal University of Goiás - Brazil (Process CEUAUFG no. 015/11). Preparation, storage and dissection of the specimens were held in the Laboratory of Animal Anatomy at the Institute of Biological Sciences (ICB) at the Federal University of Goiás (UFG), Brazil.

After thawing the specimens were fixed and preserved in $10 \%$ aqueous formalin solution. Access to the abdominal cavity was carried out by an incision through the linea alba and removal of part of the pubis and pelvic symphysis. In order to dissect the ventral face of the lumbar and sacral regions, the colon, rectum, genitourinary organs, lumbar and sacral blood vessels, parietal peritoneum and pelvic fascia were removed. Subsequently, the ventral rami of the spinal nerves which form the sciatic and 
femoral nerves were dissected, and the pelvic limb skin was removed to allow access up to the branches responsible for the innervation of the leg and foot regions. All dissection stages were documented by drawings and digital images taken with a digital camera (Sony DSC-H50) and the terms were used in agreement with the Nomina Anatomica Veterinaria (International Committee on Veterinary Gross Anatomical Nomenclature, 2005).

\section{RESULTS}

The nerves which supply the leg and foot of the $M$. tridactyla were the saphenous (femoral nerve branch), common fibular, tibial and lateral sural cutaneous nerves (derived from the sciatic nerve) and the caudal sural cutaneous nerve (tibial nerve branch).

After its origin, the saphenous nerve crosses through the femoral canal in the direction of the femoral triangle on the medial surface of the thigh. Throughout its course, it branches to the skin of this region and, after crossing the medial surface of the stifle joint, it reaches the leg, where it sprouts cranial and medial cutaneous branches to innervate the craniomedial surface of this segment (Figure 1A).
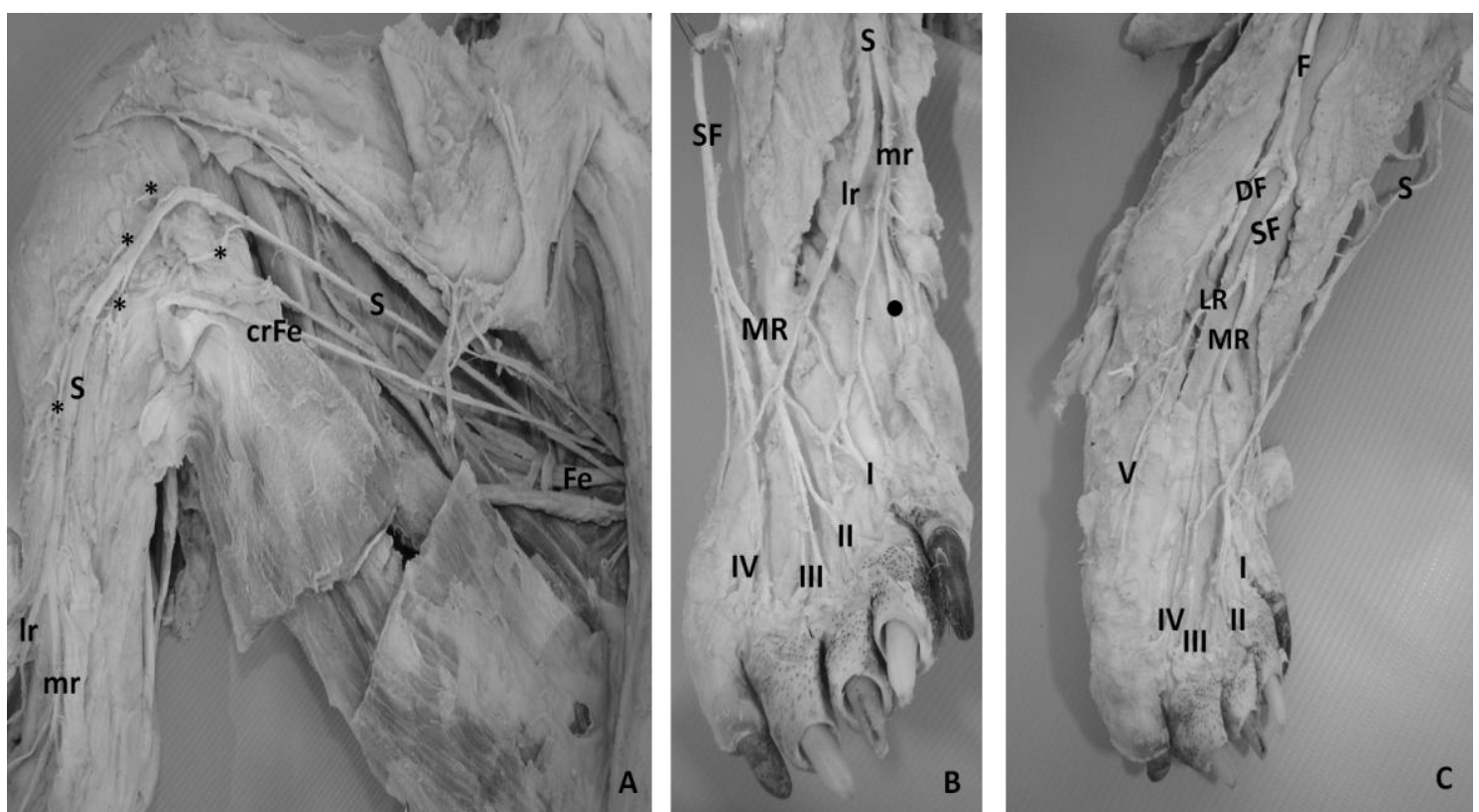

Figure 1. A- Medial view of the thigh and leg of an adult $M$. tridactyla. Fe. Femoral nerve, crFe. Cutaneous ramus of the femoral nerve, S. Saphenous nerve and its lateral (lr) and medial (mr) rami, * Cutaneous ramus of the saphenous nerve. B and C-Dorsal view of the right foot of an adult $M$. tridactyla. F. Common fibular nerve, SF. Superficial fibular nerve and its medial (MR) and lateral (LR) rami, DF. Deep fibular nerve, S. Saphenous nerve and its lateral (lr) and medial (mr) rami, I-IV. Dorsal digital nerves I-IV, • Medial proper dorsal digital nerve I.

At the distal third of the leg, the saphenous nerve branches to the skin of the medial surface of the tarsus and metatarsus; distally to the tarsus, it splits into two branches: medial and lateral. The medial ramus emits the lateral dorsal digital nerve I, the dorsal common digital nerve I and a ramus to the dorsal common digital nerve II.

The lateral ramus forms a plexiform structure at the dorsum of the foot, where it joins the medial ramus of the superficial fibular nerve. Branches from this plexus reinforce the common dorsal digital nerves I and II in both antimeres. However, in six antimeres (50\%), it springs out a ramus to the dorsal common digital nerve III (ramus of the superficial fibular nerve) and in three antimeres $(25 \%)$, it sends a ramus to the dorsal common digital nerve IV (Figure 1B and Table 1).

The sciatic nerve is the largest nerve in the sacral plexus of the $M$. tridactyla and is formed by the 
last lumbar segment and the three or four first sacral segments. After its origin, it crosses the greater sciatic foramen in the distal direction and ends up splitting into the lateral sural cutaneous, common fibular and tibial nerves at the distal third of the thigh (Figure 2A).
After arising from the sciatic nerve, the lateral sural cutaneous nerve follows the craniolateral fascia of the thigh between the femoral biceps and the femur, and splits into many rami which follow up to the craniolateral cutaneous region of the stifle joint and leg (Figure 2A).

Table 1. Digital nerves of the foot of M. tridactyla

\begin{tabular}{|c|c|c|c|c|c|c|c|c|}
\hline \multirow[b]{2}{*}{ Digit } & \multirow[b]{2}{*}{ Surface } & \multicolumn{2}{|c|}{$\begin{array}{c}\text { Common fibular } \mathrm{n} . \\
\mathrm{SF}\end{array}$} & \multirow[b]{2}{*}{ DF } & \multirow{2}{*}{$\begin{array}{c}\text { Tibial n. } \\
\text { MP }\end{array}$} & \multirow[b]{2}{*}{ LP } & \multicolumn{2}{|c|}{ Saphenous n. } \\
\hline & & MR & LR & & & & MR & LR \\
\hline \multirow{2}{*}{ I } & Dorsal & & & & & & $\mathrm{X}$ & $\mathrm{X}$ \\
\hline & Plantar & & & & $\mathrm{X}$ & & & \\
\hline \multirow{2}{*}{ II } & Dorsal & X & & & & & $X$ & $X$ \\
\hline & Plantar & & & & $\mathrm{X}$ & & & \\
\hline \multirow{2}{*}{ III } & Dorsal & $X$ & & & & & & $X(50 \%)$ \\
\hline & Plantar & & & & $\mathrm{X}$ & & & \\
\hline \multirow{2}{*}{ IV } & Dorsal & $\mathrm{X}$ & $\mathrm{X}$ & & & & & $X(25 \%)$ \\
\hline & Plantar & & & & & $\mathrm{X}$ & & \\
\hline \multirow{2}{*}{ V } & Dorsal & & $\mathrm{X}$ & & & & & \\
\hline & Plantar & & & & & $X$ & & \\
\hline
\end{tabular}

SF. Superficial fibular nerve, DF. Deep fibular nerve, MP. Medial plantar nerve, LP. Lateral plantar nerve, MR. Medial ramjus, LR. Lateral ramus.
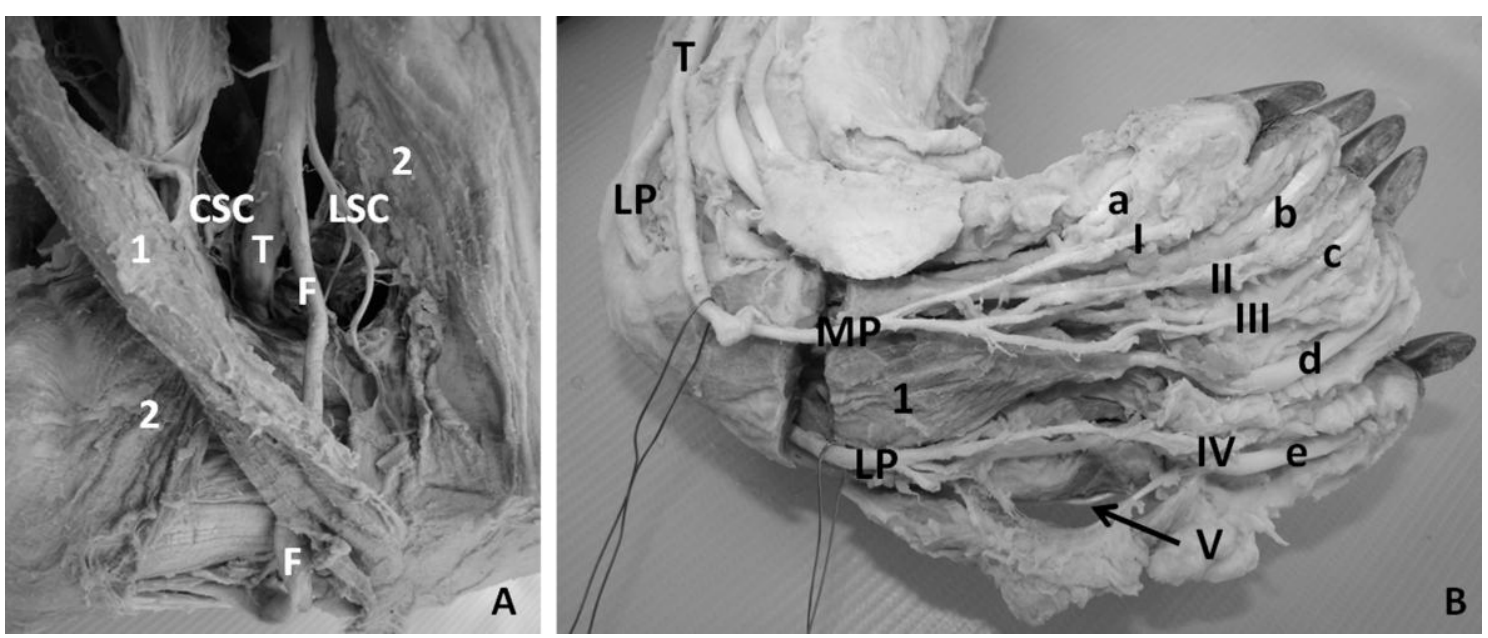

Figure 2. A- Lateral view of the distal extremity of the thigh and proximal extremity of the right leg of $M$. tridactyla. T. Tibial nerve, F. Common fibular nerve, LSC. Lateral sural cutaneous nerve, CSC. Caudal sural cutaneous nerve, 1. M. biceps femoris longus, 2. M. biceps femoris brevis. B- Plantar surface of the left foot of M. tridactyla. T. Tibial nerve, LP. Lateral plantar nerve, MP. Medial plantar nerve (Branches of the tibial nerve), I-IV. Common plantar digital nerves, V. lateral proper dorsal digital nerve V, 1. M. flexor brevis digiti, a. Tendon of the M. flexor pollicis brevis, b, c and d. Tendons of the M. flexor brevis digitorum, e. Tendon of the M. flexor digiti quinti brevis.

Upon leaving the sciatic nerve at the distal third of the thigh, the common fibular nerve runs downward across the craniolateral surface of the thigh, where it becomes related to the lateral sural cutaneous nerve. Next, it crosses between the distal extremity of the femoral biceps and the proximal extremity of the lateral head of the gastrocnemius, emerging at the proximal third of 
the lateral surface of the leg, distally to the condyle of the fibula. It then dips between the long digital extensor and long fibular muscles. Throughout its course, it supplies the long and short fibular muscles, the cranial tibial and the long digital extensor muscles.

The common fibular nerve splits into the superficial and deep fibular nerves at the level of the middle third of the leg. (Figure 1C). The superficial fibular nerve runs distally in contact with the lateral surface of the long digital extensor muscle and, in $50 \%$ of the cases, it splits into medial and lateral rami at the craniolateral surface of the tibiotarsal articulation. The other $50 \%$ split more distally at the proximal region of the metatarsus, where two rami are emitted.

These rami establish connections in various ways to innervate the dorsal surface of the foot, making it difficult to establish a standard for the species. In general, the lateral ramus gives off the lateral proper dorsal digital nerve $\mathrm{V}$ and occasionally the dorsal common digital nerve IV. The medial ramus gives off cutaneous rami to the dorsum of the tarsus and metatarsus, and also branches to join rami of the saphenous nerve to form the dorsal common digital nerves II, III and IV (Figure 1C and Table 1).

The deep fibular nerve runs cranially up to the tibia and the tibiotarsal joint, continuing deeply to the belly of the extensor hallucis longus, to which it branches and ends up dividing in the short digital extensor muscles.

The tibial nerve is the main continuation of the sciatic nerve in its course through the distal third of the thigh. In the deep surface of the biceps femoris brevis muscle, it gives off the caudal sural cutaneous nerve (Figure 2A), responsible for the cutaneous innervation of the caudal surface of the leg.

After sending the caudal sural cutaneous nerve, the tibial nerve extends distally between the medial and lateral heads of the gastrocnemius muscle reaching the caudomedial region of the leg. On its course, it branches to the gastrocnemius, plantar, soleus, long digital flexor, caudal tibial, flexor pollicis longus and popliteus muscles.
After innervating the caudal musculature of the leg, the tibial nerve travels distally between the medial head of the gastrocnemius and the soleus muscles to the middle third of the leg, where it deviates medially and superficially while crossing the distal surface of the muscular belly of the medial head of the gastrocnemius. In this route, it runs alongside with the rete mirabile of the medial plantar artery and, at the middle third of the leg, springs out two branches to the skin of the caudal surface of the leg.

At the distal third of the leg, the tibial nerve splits into medial and lateral plantar nerves, which are responsible for the innervation of the flexor digitorum brevis, quadratus plantae, flexor digiti $\mathrm{V}$, abductor digiti $\mathrm{V}$, abductor brevis digiti $\mathrm{I}$, abductor metatarsal $\mathrm{V}$, adductor brevis digiti I, adductor digiti II, flexor brevis digiti I, interossei and lumbricales muscles.

On the plantar surface of the tarsometatarsal joint, the medial plantar nerve splits into three branches, which give off muscular branches and continue as common digital plantar nerves of the digits I, II and III (Figure 2B and Table 1).

The lateral plantar nerve divides at the same level as the medial plantar nerve into the common digital plantar nerve IV and the proper plantar nerve V (Figure 2B and Table 1). Each digital nerve splits into the proper digital nerves at the level of the distal interphalangeal articulation.

\section{DISCUSSION}

There are many studies related to the origin and distribution of the sciatic and femoral nerves (Campos et al., 2003; Guimarães et al., 2005; Santos et al., 2006; Lima et al., 2008; Moraes et al., 2008; Aydin, 2009; Castro et al., 2009; Lizardo et al., 2009; Oliveira et al., 2010; Iglesias et al., 2011; Martinez-Pereira and Rickes, 2011; Oliveira et al., 2011; Pereira et al., 2011; Silva et al., 2011). However, the anatomy of the rami which branch from these nerves reaching the leg remains unknown in most of these species, since the authors rarely address the distribution of nerves distally to the knee. Possibly due to the difficulty in the dissection process, the cutaneous rami of the plantar and dorsal nerves of the foot are even less addressed, having been described in full only in the 
porcupine (Aydin, 2009) and partially in the sea lion (Castro et al., 2009) and the chinchilla (Martinez-Pereira and Rickes, 2011).

The nerves of the lumbosacral plexus responsible for the innervation of the foot and leg of the $M$. tridactyla were the saphenous, common fibular, tibial, caudal cutaneous sural and lateral cutaneous sural nerves, which coincides to reports in domestic (Getty, 1986; Schaller, 1999; Köning and Liebich 2004; Lorenz and Kornegay, 2006; Dyce et al., 2010) and wild animals (Erden, 1993; Aydin, 2009; Castro et al., 2009).

The distribution of the saphenous nerve on the cranial and medial surface of the leg of the $M$. tridactyla was similar to that described in domestic animals (Getty, 1986; Lizardo et al., 2009; Dyce et al., 2010). Among wild animals, its distribution was addressed in the sea lion (Castro et al., 2009), in which the territory of innervation was restricted to the sural ventrolateral region, which differs from that observed in this study.

A plexiform structure was formed by the saphenous and fibular nerves in the foot of the M. tridactyla, which is a feature also described in dogs and cats by Getty (1986). However, the author does not specify which digits the rami of this plexus lead to. In pigs, the same author reports that the saphenous nerve splits into lateral and medial rami at the distal third of the leg, as presented in this study. The lateral ramus joins the medial ramus of the superficial fibular nerve to form the dorsal common digital nerve II, while the medial ramus descends as the dorsal medial digital nerve II. In the M. tridactyla, apart from digit II, digits III and IV also receive branches from the saphenous nerve, which is not reported as a feature in any other species.

The sciatic nerve in the $M$. tridactyla ends by dividing into the lateral sural cutaneous nerve, common fibular and tibial nerves. This division is more distal than that observed in domestic animals (Getty, 1986), in the sea lion (Castro et $a l ., 2009)$ and in the crab-eating raccoon (Pereira et al., 2011), in which the ramification usually occurs after the sciatic nerve reaches the thigh or even in its middle third.

The origin of the caudal sural cutaneous nerve varies among different species. In the $M$. tridactyla, as in the porcupine (Aydin, 2009), it arises from the tibial nerve. In dogs and bovines (Getty, 1986), sea lions (Castro et al., 2009) and in the chinchilla (Martinez-Pereira and Rickes, 2011), it arises directly from the sciatic nerve.

The same occurs with the origin of the lateral sural cutaneous nerve. It branches directly from the sciatic nerve in dogs (Getty, 1986) and in the chinchilla (Martinez-Pereira and Rickes, 2011), as observed in this study. On the other hand, Aydin (2009) in the porcupine, Schaller (1999), König and Liebich (2004) and Dyce et al. (2010), in domestic animals, describe it as a branch of the common fibular nerve.

The division of the common fibular nerve into superficial and deep fibular nerves occurs as soon as the common fibular nerve emerges in the leg (Getty, 1986; Schaller, 1999; König and Liebich, 2004; Castro et al., 2009). Nevertheless, in the $M$. tridactyla this division takes place at the level of the middle third of the leg. As a consequence, the craniolateral muscles of the leg of the $M$. tridactyla are innervated by branches directly from the common fibular nerve, not by branches from the superficial and deep fibular nerves as in other species.

The muscular rami that branch directly off the common fibular nerve in the $M$. tridactyla were addressed to the long fibular, short fibular, cranial tibial and long digital extensor muscles, which are all innervated by the deep fibular nerve in domestic animals (Getty, 1986). Therefore, the deep fibular nerve in the $M$. tridactyla only innervates two muscles: the extensor hallucis longus and the extensor digitorum brevis.

The lateral digital extensor muscle and the fifth fibular muscle are mentioned by Schaller (1999) and Castro et al. (2009), respectively, as innervated by the superficial fibular nerve, but they are absent in the M. tridactyla.

Apart from the motor innervation of the tarsal flexor and digital extensor muscles, Miller (1964) and Dyce et al. (2010) also mention the sensitive innervation of the foot structures. It is intermediated by the union of dorsal metatarsal structures derived from the deep fibular nerve with dorsal digital rami, which in turn are derived from the superficial fibular nerve. This 
does not occur in the $M$. tridactyla, since the deep fibular nerve does not send dorsal metatarsal branches.

In the $M$. tridactyla, the tibial nerve innervates the gastrocnemius, plantar, soleus, long flexor of the digits, caudal tibial, flexor hallucis longus and popliteus muscles, in accordance to that described in humans (Gilroy et al., 2008). This is possibly due to the muscular similarity between these two species. The division of the tibial nerve into medial and lateral plantar nerves corroborates the pattern described in the other species (Miller, 1964; Getty, 1986; König and Liebich, 2004; Gilroy et al., 2008; Dyce et al., 2010). However, the formation of the digital nerves is directly correlated to the number of digits in such a manner that the distal distribution of this nerve was closer to that reported in animals with a larger number of digits, such as carnivores. Thus, the ramification of the medial and the lateral plantar nerves for the formation of the common digital nerves was in accordance to what Schaller (1999) described in swine. Nonetheless, Miller (1964) and Schaller (1999) described the plantar digital nerves in dogs as derived from the lateral plantar nerve since the two join to form the common digital nerve. This was not observed in the $M$. tridactyla.

In conclusion, the nerves responsible for the innervation of the leg and foot of the $M$. tridactyla were the same as those reported in domestic and wild animals with a few differences. The division of the common fibular nerve is more distal, which results in significant differences in the innervation of the leg muscles in relation to the standard described in domestic animals. The absence of dorsal metatarsal branches of the deep fibular nerve to innervate the dorsum of the foot was recorded. The participation of the saphenous nerve in the digital innervation is more effective, also contributing with branches to the digits III and IV, apart from the digits I and II.

\section{ACKNOWLEDGEMENTS}

The authors would like to thank IBAMA Brazilian Institute of Environment and Renewable Natural Resources for donating the $M$. tridactyla specimens used in this study.

\section{REFERENCES}

AYDIN, A. The dissemination of the pelvic limb nerves originating from the lumbosacral plexus in the porcupine (Hystrix cristata). Vet. Med-Cezech, v.54, p.333-339, 2009.

BRAGA, F.G. Plano de conservação para tamanduá-bandeira (Myrmecophaga tridactyla). In: BRAGA, F.G. Instituto Ambiental do Paraná, Planos de ação para Espécies de mamíferos ameaçados. IAP: Curitiba, 2009. p.14-30.

BARRETO, A. Tamanduás-bandeira e sua vulnerabilidade. Clin. Vet., v.68, p.12-16, 2007.

CAMPOS, D.B.; SILVA, F.O.C.; SEVERINO R.S. et al. Origem e distribuição dos nervos isquiáticos em fetos de bovinos azebuados. Ars Vet., v.19, p.219-223, 2003.

CASTRO, T.F.; SOUZA, D.A.S.; SILVA FILHO, R.P.; PEREIRA, M.A.M. Sistematização e distribuição da inervação lombar e sacral em Arctocephalus australis. Braz. J. Vet. Res. Anim. Sci., v.46, p.404-411, 2009.

DYCE, K.M.; SACK, W.O.; WENSING, C.J.G. Tratado de anatomia veterinária, 4.ed. Rio de Janeiro: Editora Elsevier, 2010. 834p.

ERDEN, H. Merkebin (equus asinus 1.) plexus lumbosacralis'I üzerinde makroanatomik ve subgros çalişmalar. S. Ü. Vet. Fak. Derg., v.9, p.64-71, 1993.

GETTY, R. Anatomia dos animais domésticos. 5.ed. Rio de Janeiro: Guanabara Koogan, 1986. 2000p.

GILROY, A.M.; MACPHERSON, B.R.; ROSS L.M. Atlas de Anatomia. Rio de Janeiro: Guanabara Koogan, 2008. 656p.

GUIMARÃES, G.C.; MACHADO, M.R.F.; SANTOS, A.L.Q. et al. Origem e distribuição do nervo isquiático no gato doméstico (Felis catus domesticus, Linnareus, 1758), Biosci. J., v.21, p.189-195, 2005.

IGLESIAS, L.P.; SILVA, F.O.C.; BRITO. T.R. Origem e distribuição do nervo isquiático em fetos de javalis (Sus scrofa scrofa). Biotemas, v.24, p.141-145, 2011. 
INTERNATIONAL COMMITTEE ON VETERINARY GROSS ANATOMICAL NOMENCLATURE. Nomina anatomica veterinaria. 5.ed. Ithaca: Cornell University, 2005. 190p.

IUCN, Red List of Threatened Species. Version 2012.1. Disponível em: <http//www.iucnredlist.org>. Acessado em: 26 Ago. 2012.

KÖNIG, H.E.; LIEBICH, H.J. Anatomia dos animais domésticos. Porto Alegre: Artmed, v.2, 2004. 399p.

LIMA, E.M.M.; SILVA, F.O.C.; SEVERINO, R.S. et al. Origem e distribuição dos nervos isquiáticos em caprinos da raça Saanen. Cienc. Rural, v.38, p.372-377, 2008.

LIZARDO, F.B.; SILVA, F.O.C.; SEVERINO, R.S. et al. Origin and distribution of the femoral nerve in fetuses of zebu-crossed bovines. Braz. J. Morphol. Sci., v.26, p.91-96, 2009.

LORENZ, M.D.; KORNEGAY, J.N. Neurologia Veterinária. 2.ed. Barueri: Manole, 2006. 467p.

MARTINEZ-PEREIRA, M.A.; RICKES, E.M. The spinal nerves that constitute the lumbosacral plexus and their distribution in the chinchilla. $J$. S. Afri. Vet. Ass., v.82, p.150-154, 2011.

MILLER, M.E. Anatomy of the dog. Philadelphia: W. B. Saunders, 1964. 941 p.

MORAES, D.V.; MARTINS, J.D.; SILVA, F.O.C. et al. Origem e distribuição do nervo femoral em equinos sem raça definida. Rev. Hor. Cient., v.1, p.1-10, 2008.

MOURÃO, G.; MEDRI, M. Activity of a specialized insectivorous mammal (Myrmecophaga tridactyla) in the Pantanal of Brazil. J. Zool., v.271, p.187-192, 2007.
OLIVEIRA, G.B.; RODRIGUES, M.N.; SOUSA, E.S. et al. Origem e distribuição dos nervos isquiáticos do preá. Cienc. Rural, v.40, p.1741-1745, 2010.

OLIVEIRA, G.B.; ALBUQUERQUE，J.F.G.; RODRIGUES, M.N. et al. Origem e distribuição do nervo femoral em mocó, Kerodon rupestris (Cavidae). Pesq. Vet. Bras., v.31, p.84-88, 2011.

PEREIRA, K.F.; PARANAIBA, J.F.F.S.; HELRIGLE, C.; ARAÚJO, E.G. Origem e distribuição anatômica do nervo isquiático de mão-pelada. Pesq. Vet. Bras., v.31, p.74-78, 2011.

SANTOS, R.C.; ALBUQUERQUE, J.F.G.; SILVA, M.C.V. et al. Anatomia do nervo isquiático em mocós (Kerodon rupestris WIED, 1820) aplicada a clínica de animais silvestres. Braz. J. Vet. Res. Anim. Sci., v.43, p.647-653, 2006.

SCHALLER, O. Nomenclatura anatômica veterinária ilustrada. São Paulo: Manole, 1999. 494p.

SHAW, J.H.; MACHADO-NETO, J.; CARTER, T.S. Behavior of free-living giant anteaters (Myrmecophaga tridactyla). Biotropica, v.19, p.255-259, 1987.

SILVA, F.O.C.; BRITO, T.R.; VASCONCELOS, B.G. et al. Origens e distribuições dos nervos femorais em ovinos sem raça definida. Biosci. J., v.27, p.978-981, 2011.

SILVEIRA, L.; RODRIGUES, F.H.G.; JACOMO, A.T.D.; DINIZ, J.H.F. Impact of wildfires on the megafauna of Emas National Park, central Brazil. Oryx, v.33, p.108-114, 1999.

VIZCAÍNO, S.F.; LOUGHRY, W.J. The Biology of the Xenarthra. Gainesville: University Press of Florida, 2008. 370p. 